\title{
SNAPSHOT 3: WHAT THE TALLER DE INVESTIGACIÓN TEATRAL REVEALED TO ME \\ Etzel Cardeña
}

Deborah Middleton's loving invitation to contribute to the new edition of Anthropocosmic Theatre could not have come at a better time: I was in the midst of writing an academic paper on altered consciousness and enhanced psychophysiological functions and had considered including my personal experiences. I decided against it because I wanted the reader to focus on the research evidence. Yet, in various interviews throughout the years I have stated that my interest in the psychology of alterations of consciousness sprang from my experiences doing experimental theatre during my 20s, initially in UNAM's Taller de Investigación Teatral, led in the late 1980s by Nicolás Núñez and Helena Guardia (my theatre activities as director and actor have naturally also been also informed by this work). Here are two examples that stand out:

One late afternoon, the Taller members (besides the leaders it included Marcela Camacho, Alejandro (Bracho) Rojas, Jaime Soriano, and a few others) went to a nearly 4,000-meter high dome volcano to the south of Mexico City, El Ajusco. It was a fairly cold afternoon even at the bottom of the volcano and our goal was to walk up the volcano silently and mindfully. As I started my ascent, I experienced that my body was effortlessly moving as a harmonious and agile unit, as if my legs knew exactly how to climb this new terrain, without any need to think about what I was doing or even look at the ground in front of me. Contrary to my typical physical caution and awkwardness, I was climbing with an assurance and speed I had not experienced before, and the cold did not bother me. This body know-how felt so natural and in tune with the surroundings that I decided on the spot to feel less encumbered and take off my clothes, shoes, and socks to continue the ascent. Some members of the Taller told me then that I would get injured 
and/or sick given the considerable cold and stones and other obstacles on the way. I responded that as long as I remained in the state I was in everything would go well (as, in fact, it did). This was years before I had even heard of the concept of flow (a state of full immersion, effectiveness, and enjoyment in an activity) or meditative techniques such as G Tum-mo that allow Tibetan monks to dry clothes dipped in freezing water on their backs after generating bodily heat, but some part of me was already aware of this (see Cardeña, in press, for a review of research on the topic).

The other event was even more striking to me and I proudly bear a scar to prove it. Two other members of the Taller and I prepared a scene using a text by Samuel Beckett. The scene we performed at one of the theatres of México's National University was an invocation of the devil (I apologize retrospectively for completely mangling the text by Beckett, which had nothing to do with our performance). The reinterpretation was that I, as magician, would draw a magical circle and summon the devil, whom I would only observe through a mirror because it would be very dangerous to see it directly. In the background, a Taller member was playing a drum and my friend Alejandro started coming down from the back of the audience space onto the stage impersonating the devil. I was intensely absorbed in the scene and suddenly, for no reason I can think of, the framed mirror I was holding shattered. One large shard pierced my hand, which started to bleed profusely, but I felt no pain whatsoever. In the midst of that droning darkness, relieved only by lit black candles, we finished the scene, after I had just enough energy to blow out the candles. It has been my most intense performance experience, and it would be some years before I read that intense focus on hypnosis, meditation, and similar contexts can dampen or even eliminate pain and affect bleeding, and that there is scientific evidence that mental intentions may affect matter directly (Cardeña, 2018, in press).

These two experiences occurred within a larger personal transformation that owed much to the work in the Taller. I had been a precocious child and teen, but my development as a person had been very slanted towards 
intellectual endeavors. My body felt somewhat alien despite my being a good table tennis and tennis player, because in sports I only 'employed' my body instrumentally to carry out specialized movements to obtain some goals (e.g., win the point).

I did not experience my body as the centre of my sensual and living universe, and felt almost always a split between my intentions and their bodily enactments. Even before becoming a member of the Taller, I had discovered what I later called the truthful trickery of acting, how the Stanislavskian 'asif' (or in the same construct in hypnosis, a 'believed-in-imaging') can turn an initial falsehood into an experiential and physiological reality (Cardeña $\&$ Beard, 1996). Yet it was still a very long way for me to become aware of the gift I had and to trust and enjoy my vibrant body/mind, undivided in itself and in its encounter with others. The challenges of the Taller (and later in training with Stephen Rumbelow and others), like mindfully running or doing other activities well beyond exhaustion, silenced my inner monologue and tapped a state of greater endurance and awareness. Engaging in risky actions that demanded full attention and commitment short-circuited my (ir)rational meandering and physical hesitations, allowing for the emergence of potentials far surpassing my conscious self. My body was no longer a vehicle to 'use', but a source of astounding revelations and sensibility, preciously unique but also part of a much larger process 'within' and 'without'. Gradually, and at times punctuated by fulgurating experiences like those described earlier, I became a far more integrated human being, and for that I will always be grateful to the Taller.

\section{REFERENCES}

Cardeña, Etzel (in press). 'Derangement of the senses or alternate epistemological pathways? Altered consciousness and enhanced functioning'. Psychology of Consciousness: Theory, Research, and Practice.

Cardeña, E. (2018). 'The experimental evidence for parapsychological phenomena: A review'. American Psychologist, 73, 663-677. 
ANTHROPOCOSMIC THEATRE

Cardeña, Etzel, \& Beard, J. (1996). 'Truthful trickery: Shamanism, acting and reality'. Performance Research, 1, 31-39. 